\title{
The Consumerism Culture in "American Tragedy"
}

\author{
Shuai Chen \\ School of Foreign Languages \\ Huanghe Science and Technology College \\ Zhengzhou, China 450063
}

\begin{abstract}
Theodore Dreiser, the famous American novelist, created a capitalist world filled with materialistic desires and consumerism in American Tragedy, one of his masterpieces. All the characters in the novel, without exception, have been blinded by materialism and have gradually abandoned the traditional ethics in the mad pursuit of the material world. The hero's chasing and longing for tangible goods is actually the psychological demands of social status and identity which symbolizes these consumption goods, and the hero's falling psychological process is actually the one in which the hero's psychology has been alienated by the consumerism culture. In this paper, the author comprehensively explores the consumerism culture in American Tragedy through analyzing the hero's pursuit of clothes, private cars, houses and other goods, and reveals the roots of the tragedy of the novel ---- the irrational conspicuous consumption.
\end{abstract}

Keywords-American Tragedy; consumerism culture; conspicuous consumption

\section{INTRODUCTION}

The United States is in a period of social transition in the late 19th and early 20th century, showing a trend of change from a production-based society to a consumption-based one. With the completion of the industrial revolution, the US economy has achieved rapid development, the pace of urbanization has gradually been accelerated, and the spiritual life has also undergone a major shift. The traditional ethics controlled by Puritanism has gradually lost its influence under the effect of the emerging consumerism culture. Movies and literature full of consumerism culture spread into every corner of people's lives. Theodore Dreiser shows this scene in his novel American Tragedy. The realism novelist shows, in a unique literary way, people's chasing and longing for clothing, private cars and houses in American society, and people's confusion and contradiction in their minds under the influence of this consumerism culture. The author, in this paper, analyzes Dreiser's attitude towards this consumption culture through exploring the consumerism culture in the novel American Tragedy.

Clothing is the Symbol of one's Social Class. Consumerism culture is the sense of community in the transitional period of US economy, in which clothing has become a symbol of the individual class and appearance has become an important standard to measure the value of the individual, and the luxury clothing has becomes a demonstration of a person's financial resources. Being unable to consume luxury clothing represents a low social class. Thus, clothing has undoubtedly been given a symbolic value in the novel American Tragedy, becoming a symbol of individual social strata.

In the first few chapters of the novel, the author Dreiser uses a lot of ink to show Clyde's thoughts on clothing, fully revealing the individual's anxiety about their social class and their urgent desire to join in upper-class society under the influence of consumerism culture. Clyde, the hero in the novel, is clearly unable to meet this demand for clothing in the beginning, so he often feels upset and affronted. He is always calling in his deep heart: "God, ah, give me bright shoes, smooth shirt, handsome jacket and luxury suit." Clyde's thought of clothing is actually a reflection of the consciousness of the whole society. Clyde's social environment renders him gradually aware of the social significance of costumes that they imply. Clothes seem to have become a symbol of social class, and the symbolic value that gorgeous costumes have can satisfy Clyde's psychological demands to be recognized by the society.

In the era of conspicuous consumption concept, clothes have, to some extent, evolved into social equipment, and it has become a status symbol. As to Clyde, a new set of clothes is very likely to create a new self and a set of decent clothes can let him accepted by the mainstream society, and then he can enjoy all the fun this group provides. Otherwise, all dreams will become out of reach. In this consumption attitude, the symbolic value of clothes far outweighs its use value. You will be accepted by different social class by what you wear. Clyde gradually understand this consumption culture after entering into the community, therefore, when he receives a dinner invitation from his uncle, he can not wait to use all his savings buying an outfit for himself although it clearly says in the invitation that this is not a formal dinner. And the changes of his aunt's attitude toward him after the dinner made him aware of the symbolism of clothing again.

Under the influence of consumerism philosophy, costumes have not only become a person's identity tag, but also it determines his family status. Clyde has worked in his uncle's garment factory for some time, when his uncle saw his nephew wearing a sleeveless shirt in the crowd, he can not see his nephew's elegance or decency at the banquet, which without doubt will seriously affect the family's reputation in the outside world, and therefore, he immediately decided to promote Clyde. He arranges his nephew in a position in which he can wear decent clothes, so Clyde seems like a member of the mainstream of society. In 
the eyes of his uncle, Clyde is only a mannequin packaged with costumes. He must dress like a member of the Geliefeisi family no matter where he is. A decent dress becomes the effective way for Clyde to achieve his family status. Clothing has become an important standard to measure an individual's social status, and the process of change for Clyde's clothing reflects his different stages of pursuit of social status, from being almost naked when he follows his missionary parents in the streets to being in uniform at work in a hotel, from a decent suit when attend a dinner in his uncle's house to a sleeveless shirt in the garment factory in the basement, from the fancy costume with the wealthy daughter to the prison uniform in jail. It is not difficult to find Clyde's craving and longing for the upper social class from the changes in his clothing.

Especially when describing Clyde killing his exgirlfriend, the author shows Clyde's longing for the symbolic meaning that clothes represent with a series of details. After making sure that his ex-girlfriend drowned, Clyde tied the pieces of wet clothes to a stone and tried his best to throw it into the lake, and then put on a decent dress. At this time, Clyde seems to have gotten rid of the past life, and get a new social identity.

However, the symbolic role of clothing is very unstable. The author reveals the deception of the symbolism of clothing with details description. Clyde's cousin considered the fake collar their garment factory produces has important social significance and the fake collar makes it possible for consumers, who can not afford to buy shirts, to appear decent. The value of these fake collars lie mainly in their symbolic values, and its aesthetic value far outweighs its use value. These fake collars can shorten the distance between social classes, the consumers are trying to eliminate the social disparities caused by different spending power. For Clyde, the decent clothing is his key to enter the mainstream of society, and for the mainstream social group, clothing is a valid tag standing for their unique value.

\section{PRIVATE CARS SYMBOLIZE ONE'S SOCIAL IDENTITY}

The private car plays an important role in promoting the development of the plot in American Tragedy, at the same time, it is also an important factor to change the fate of the hero. After giving up a missionary life, Clyde begins to focus on private cars when entering into the society to seek a new life. His ultimate desire for private cars is virtually the pursuit of status that private cars symbolize. Private cars exist in all the key scenarios in American Tragedy, which is not an accident, because the author is aware of the symbolism the private car carries at that time.

In the consumption culture, the use function of items lies in a secondary position, instead, the symbolic value of items is the important means for people to pursue a certain identity. Private cars represent prestige and status at that period of time in American society. Clyde's pursuit of private cars is actually a thirst for the identity that private cars carry. Based on this notion, Clyde is very envious of the cars parked around the hotel, and one of his colleagues at the hotel boast around simply because he has a friend who can borrow a car.
Clyde is gradually aware of the fact that cars are symbols of identity and status; as a result, he desperately wants to win the favor of Hortense, his beloved girl through the means of cars. Hortense clearly knows the symbolic value of private cars, so she tells a lie that a man owning a private car is also pursuing her in order to induce Clyde to buy gifts for her. Hortense, meanwhile, places private cars as an important standard of choosing her husband. After stealing a car, Clyde excitedly races in the snow, and the anxiety of stealing is completely forgotten. Finally his dream ends with the rollover of the luxury car. Till then, Clyde ends the first stage of his life, at the same time the first step of his tragic life also starts.

When Clyde enters into his uncle's house, what he notices first is a brand- new car parked in front of the garage and another parked in the garage. This picture even makes Clyde feel dizzy. While for his uncle, it is the biggest bragging capital to have more private cars. At that time, people's quest for cars not only meets the demands of life, but more importantly, it means possession of the status and identity private cars carry. It is a powerful mean to be different from others. All the wealthy people mentioned in American Tragedy regard the luxury car as a symbol of personal status and identity. The reason why they uphold this consumerism is that they want to experience this superior life and the feeling to show off through consumption.

It is Clyde's dream for private cars that constitutes the second turning point of his life. In the beautiful moonlight, elegant and noble Sandra stops the car beside Clyde. She mistakes Clyde for his cousin, and she goes straight to Clyde. In order to make up for the embarrassment, Sandra offers Clyde a ride in her private car. Clyde being eager to rank among the upper class will certainly not miss this opportunity, and he takes this as an opportunity to launch a fierce pursuit of Sandra. Since then, whenever he sees colorful and distinctive cars, he will feel his desire for such a necessity. His so-called necessity is clearly beyond the scope of material needs, and it is longing for the social statue that the private car symbolizes. In the consumerism culture at that time, private cars bear such things as identity, status, fame, and Clyde gradually lose himself around these things. He is eager to have these things, so that he can get the capital to show off. It is this abnormal consumption path that guides Clyde to the abyss of crime.

\section{HOUSES REPRESENT ONE'S SOCIAL STATUS}

In American Tragedy, the author incisively and vividly reveals the lure of the social status that a big house stands for by describing Clyde's psychological feelings of the hotel in which he works and other big houses. When Clyde decides to give up his parents' religion and begin to work in a hotel, he feels as if he entered into the paradise. He, with great respect, surveys the smooth marble pillars, colorful decorations in the hotel and the bright hall, and he takes great pride in working in such a luxurious building. When he sees customers enjoying the considerate and thoughtful service, he feels the paradise's gate has been opened for him. 
Based on the consumerism culture, the hidden wealth doesn't count, and if you want to let others know your wealth, the best way is to own big houses. This consumption concept gradually becomes the consensus of the society under all kinds of media publicity, and houses become symbols of social status and efficient codes to identify individuals. Dreiser clearly recognizes the symbolism of the residence, and tries to reveal it through the novel, so he describes the residential environment of Clyde' uncle in detail. Looking at these luxury houses, Clyde seems to see the uncle family going in and out of the mansion with pride every day. Clyde doesn't receive systematic school education with his missionary parents, and his sense of values is mainly influenced by the social environment. The social group consciousness is the guidance of his sense of values, and his value system completely follows the social mainstream consciousness, so when Clyde realizes he is standing in front of his uncle's house, his first reaction is to stand straight, because he takes pride in being connected with this mansion though this connection is negligible. Of course, what makes Clyde proud is the symbolism of social status of the mansion rather than its use value.

Apart from the decoration and scale of the house, the geographical position of it is also a very important factor to decide the social value of the residence, which determines the social class of the owner. When two cousins of Clyde hear that the families of high social status live in the lake villa, they urge their parents to draw close to the social hub, and even the always proud cousin agrees with this suggestion. Residence, as a kind of symbolic value, begins to guide the social stratification gradually. That how to consume becomes a new standard to determine human classes, and the decorations, scale and geographical position of the residence become new elements to influence social status. It is these new elements that push Clyde to go towards the villa by various means, finally kill his killing a pregnant ex-girlfriend and take the wrong path.

\section{CONCLUSION}

Above all, in American Tragedy, Dreiser exposes and criticizes the high-profile consumerism culture by describing the hero's pursuit of private cars, clothes and houses, and defines the consumption idea as morbid psychological demand, under which individualism, money worship and hedonism gradually become the mainstream of social consciousness. The high-profile consumerism culture becomes a new standard to define social classes and status. The social groups believing in this culture highlight their social values by purchasing or taking possession of all kinds of material goods. This kind of consumerism culture in essence is a kind of psychological demand, a blind pursuit of vanity status and identity.

\section{ACKNOWLEDGEMENT}

Fund Project: This article is the stage research result of the following project: survey of the market demand of industry translators and analysis of the training mode of college students majoring in English in Henan province (ID:
KYSK201314), a project approved by Huanghe College of Science and Technology in 2013.

\section{REFERENCES}

[1] Jianjuan DUAN, Criterion for Survival—on Exploring the Pursuit of the Art of prose in the New Era [J] Journal of Northwest University,2008.

[2] Xiao ZENG, Failure of the American Dream: An Analysis of the Consumption Society's Alienation of People in American Tragedy, [J] Youth,2013. 